\title{
KÜLÖNBÖZŐ SZEMCSEMÉRETÜ DURUM DARÁK SZÍNJELLEMZŐINEK ÉS HAMUTARTALMÁNAK VIZSGÁLATA
}

\section{Horváth Zsuzsanna}

\begin{abstract}
Absztrakt: A durum búzából készült darák egyik fontos minőségi jellemzője a szín, hiszen ezekböl tojás hozzáadása nélkül készítenek tésztát. Munkánk során azt vizsgáltuk, hogyan befolyásolja a durum búzából készült örlemények müszerrel mért színjellemzöit, illetve hamutartalmát a szemcseméret. Elemeztük továbbá a hamutartalom és a színjellemzők összefüggését. A szín jellemzésére a CIELab színtérben értelmezett $\mathrm{L}^{*}, \mathrm{a}^{*}, \mathrm{~b}^{*}$ színkoordinátákat alkalmaztuk. A méréseket Hunter MiniScan színmérő müszerrel végeztük. Megállapitottuk, hogy a színjellemzöket szignifikánsan $(\mathrm{p}<0,01)$ befolyásolja a szemcseméret. $\mathrm{L}^{*}$ koordináta csökken, a* és $b^{*}$ koordináta, illetve YI sárgasági index nő a szemcseméret növekedésével. Az eredmények azt is mutatták, hogy a hamutartalom és az egyes színjellemzök között szignifikáns $(\mathrm{p}<0,05)$ lineáris kapcsolat van.
\end{abstract}

Abstract: One of the quality features of semolina made of durum wheat is its colour because pasta is made from it without adding any eggs. In the course of my research I studied how the size of grains influences the colour features and cinder content of instrumentally measured milling products made of durum wheat. I also analysed the relation between cinder content and colour features. For describing the colour, I used the $\mathrm{L}^{*}, \mathrm{a}^{*}, \mathrm{~b}^{*}$ colour coordinates defined in CIELab colour space. I used Hunter MiniScan colour measurement spectophotometer. I established that colour features are significantly influenced $(\mathrm{p}<0.01)$ by the size of grains. $\mathrm{L}^{*}$ coordinate decreases while $\mathrm{a}^{*}$ and $\mathrm{b}^{*}$ coordinates and YI yellowness index increase as the size of grains changes bigger. Results also have shown that the ash content and the set of colour features have a significant $(\mathrm{p}<0.05)$ linear relation.

Kulcsszavak: durum dara, színjellemzök, hamutartalom

Keywords: semolina made of durum wheat, colour, ash content

\section{Bevezetés}

A búzaörlemények napjainkban is az egyik legfontosabb és leggyakrabban használt élelmiszer alapanyagok. Minden élelmiszeripari terméknek, így a búzaörleményeknek is fontos tulajdonsága a szín, amely már egy elsődleges képet ad a termékröl.

Hazánkban is egyre inkább elterjedtek a durum búzából készült tészták. Ezek készítéséhez nem szükséges tojást használni, tehát azok is nyugodtan fogyaszthatják, akik valamilyen okból - allergia, vegetarianizmus vagy magas koleszterintartalom kerülik a tojást tartalmazó ételeket étkezésük során. Mivel tojás nem tartalmaznak, ezért az készült tészták színének alakulását alapvetően az alapanyagául szolgáló durumdara színe határozza meg. Ez indokolja, hogy durum darák esetén a müszeres színmérést már az üzemi gyakorlatban is alkalmazzák. A szakirodalomban számos kutatási eredményről olvashatunk a búzaőrlemények színmérésével kapcsolatban.

A minősítés során Oliver et al. már 1993-ban kimutatta, hogy a hamutartalom befolyásolja a lisztek színét. A témával kapcsolatos további kutatások (Horváth et. al., 2004) kimutatták, hogy a keményebb búzákból készített lisztek L* koordinátája alacsonyabb, míg a* koordinátája magasabb, vagyis sötétebbek és barnább 
árnyalatúak, emellett $L^{*}$ világossági koordináta szoros összefüggést mutat a lisztek fehérségi indexével.

Konopka et.al. (2004) a lisztek színjellemzői és lipid valamint színezéktartalma között állapított meg összefüggést.

Halászné et al. (1995) durum darák színmérésén alapuló minősítési rendszerére tett javaslatot. D'egido és Pagani (1997) különböző technológiával őrölt durum lisztekből készített tészták színjellemzőit hasonlította össze.

A termékgyártás során elsősorban a megfelelő sültségi fok megállapítására használnak színjellemzőket (Hotti et. al., 2000). Humphries et al. (2005) összefüggést találtak a CIE b* sárgasági koordináta és a búza lutein tartalma között. Konopka et al. (2004) kapcsolatot állapított meg a lisztek színjellemzöi és a lipid valamint színezékanyag tartalma között. Gökmen és Senyuva (2006) tanulmányozta, hogy milyen hatással van a melegítés a búzalisztek színjellemzőire. László et. al. (2008) vizsgálta, az ózon, az UV és a kombinált ózon-UV sugárzás a búzalisztek színkoordinátáira. Lamsal és Faubion (2009) enzim preparátumok hatását vizsgálta liszt és a tészta $L^{*}$ világossági és b* sárgasági koordinátájára.

Munkánk során azt vizsgáltuk, hogyan befolyásolja a durumdarák mủszerrel mért színjellemzőit a szemcseméret. Azt is elemeztük, hogy milyen összefüggés van a darák színjellemzői és hamutartalma között.

\section{Anyagok és módszerek}

\subsection{A vizsgált anyagok}

Méréseinkhez 12 különböző gyártási tételből származó durum darát használtunk. A darákból 500 g-ot megfelelő szitasorozat alkalmazásạ́val, szitáló gép segítségével az alábbi szemcseméret tartományokra bontottunk:

- $160 \mu \mathrm{m}$-nél kisebb

- $\quad 160 \mu \mathrm{m}-250 \mu \mathrm{m}$

- $\quad 250 \mu \mathrm{m}-315 \mu \mathrm{m}$

- $\quad 315 \mu \mathrm{m}-500 \mu \mathrm{m}$

- $\quad 500 \mu \mathrm{m}$ felett

Ezt követően minden szemcseméret tartományú dara, illetve a teljes őrlemény esetén is színmérést végeztünk, illetve meghatároztuk a minták hamutartalmát is.

2.2. Az alkalmazott vizsgálati módszerek

\subsubsection{Az alkalmazott színjellemzök és meghatározásuk}

A színmérést Hunter MiniScan spektrum alapú színmérö készülékkel végeztük. A szín jellemzésére CIELab színtérben meghatározott $L^{*}$ világossági, a* pirossági és b* sárgasági koordinátát, valamint YI sárgasági indexet alkalmaztuk (Lukács, 1983). Minden dara minta színmérését 3 ismétlésben végeztük el, majd a mintákat a mért értékek átlagával jellemeztük. 


\subsubsection{A hamutartalom meghatározása}

A hamutartalom meghatározását az MSZ EN ISO 2171:2010 (Gabonafélék, hüvelyesek és melléktermékek. A hamu mennyiségének égetéses meghatározása) szabványnak megfelelően végeztük el.

\section{Eredmények és értékelésük}

\subsection{A szemcseméret hatása a színjellemzők alakulására}

Annak elemzésére, hogy befolyásolja-e a színjellemzőket a szemcseméret egytényezős varianciaanalízist (ANOVA) végeztünk. A Bartlett és Cochran-próba eredménye igazolta a varianciák a homogenitását, a Shapiro-Wilk próbával pedig ellenőriztük a normalitás teljesülését.

\section{1. táblázat: A különböző szemcseméret frakcióik színjellemzőinek értékelésére} végzett varianciaanalízis eredménye

\begin{tabular}{|l|c|c|}
\hline Színjellemző & F-érték & Szignifikancia szint \\
\hline $\mathrm{L}^{*}$ & 88,25 & 0,0001 \\
\hline $\mathrm{a}^{*}$ & 264,5 & 0,0001 \\
\hline $\mathrm{b}^{*}$ & 160,6 & 0,0001 \\
\hline YI & 173,2 & 0,0001 \\
\hline
\end{tabular}

\section{1. ábra: A szemcseméret hatása $\mathbf{L}$ * és a*színkoordináta alakulására (átlag} értékek a 95\%-os megbízhatósági szinthez tartozó konfidencia intervallummal)
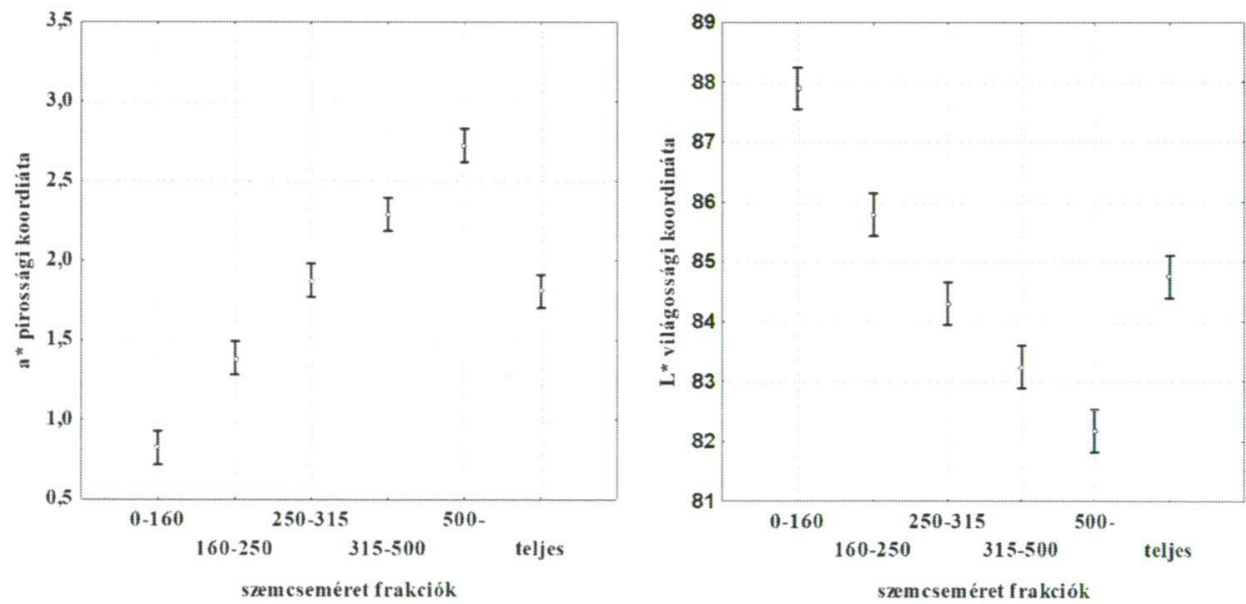

A varianciaanalízis eredményét az 1. táblázatban láthatjuk. A táblázat értékei alapján megállapíthatjuk, hogy a szemcseméretnek szignifikáns hatása van $\mathrm{L}^{*}, \mathrm{a}^{*}$, b* színkoordináták, valamint YI sárgasági index alakulására. Az 1-2. ábrákon ábrázoltuk a különböző minták egyes szemcseméret frakcióin mért színjellemzők átlag értékit a 95\%-os megbízhatósági szinthez tartozó konfidencia intervallummal. 
A 2. ábrán jól látszik, hogy a szemcseméret növekedésével L* világossági koordináta csökken. Legnagyobb a különbség a $0-160 \mu \mathrm{m}$ és $160 \mu \mathrm{m}-250 \mu \mathrm{m}$ frakciók átlaga között, de a többi esetben is legalább 1 egység a különbség. Tehát a nagyobb szemcsék sötétebbek.

\section{2. ábra: A szemcseméret hatása b* színkoordináta és YI sárgasági index alakulására (átlag értékek a 95\%-os megbízhatósági szinthez tartozó konfidencia intervallummal)}

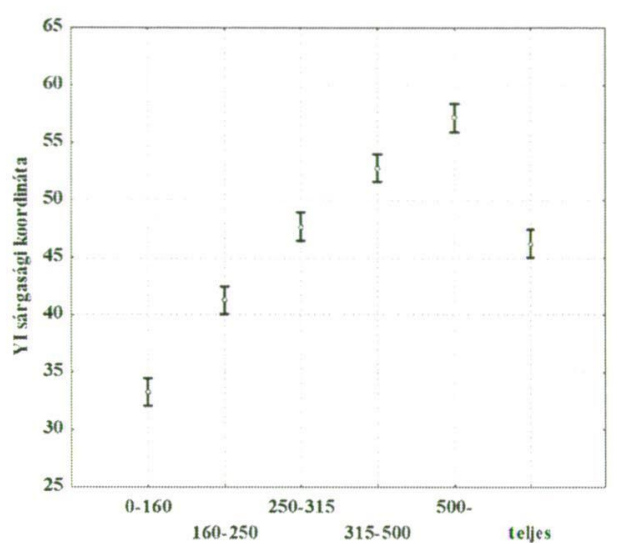

szenc se mé ret frakiók

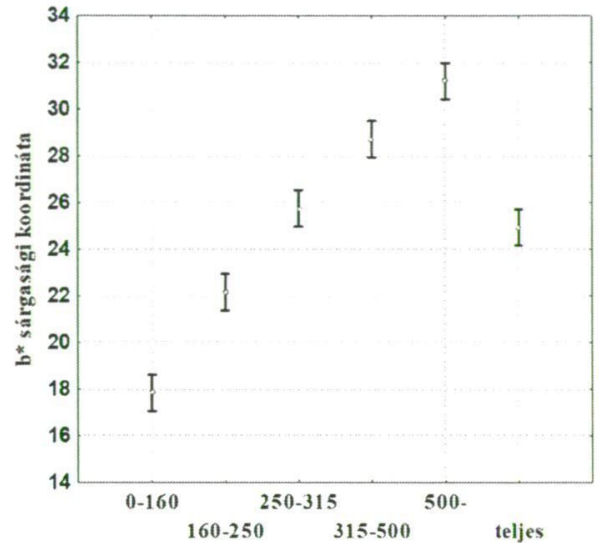

szemcsemèret frakciók

Az 1-2. ábrák azt mutatják, hogy a* pirossági koordináta, b* sárgasági koordináta és YI sárgasági index a szemcseméret növekedésével növekszik. Átlagos 0,5 egységgel $\mathrm{a}^{*}$ koordináta, 3-4 egységgel $\mathrm{b}^{*}$ koordináta és 5 egységgel YI sárgasági index. Vagyis a nagyobb szemcsék színe kissé vörösebb és erőteljesen sárgább.

\subsection{A küilönböző szemcseméret frakciójú darák hamutartalmának alakulása}

A szemcseméret hatását a hamutartalom alakulására egytényezős varianciaanalízis segítségével értékeltük. Az eredmények azt mutatja $(\mathrm{F}=35,73, \mathrm{p}=0,000)$, hogy a szemcseméret szignifikánsan befolyásolja a hamutartalom alakulását. A részletes elemzéshez a 3. ábrán láthatjuk a különböző minták egyes szemcseméret frakciók hamutartalmának átlag értékit a 95\%-os megbízhatósági szinthez tartozó konfidencia intervallummal. Az ábra azt mutatja, hogy a szemcseméret növekedésével a hamutartalom csökken. Az átlagos hamutartalom $0,7 \%$ és $1,1 \%$ között változott. $\mathrm{A}$ teljes őrlemény hamutartalma a $315 \mu \mathrm{m}-500 \mu \mathrm{m}$ frakció hamutartalmával egyezik meg. Az egymást követő szemcseméret frakciók hamutartalma között átlagosan $0,1 \%$ a különbség. 
3. ábra: A szemcseméret hatása a hamutartalom alakulására (átlag értékek a 95\% -os megbízhatósági szinthez tartozó konfidencia intervallummal)

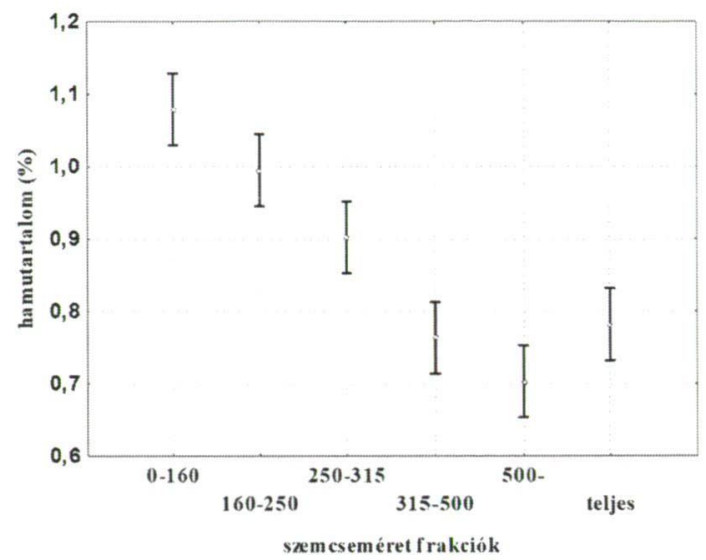

3.3. A színjellemzők és a hamutartalom összefüggés vizsgálata

Megvizsgáltuk van-e összefüggés a darák hamutartalma és az egyes színjellemzők között. A 4. ábrán láthatjuk a különböző mintákon mért L* világossági koordinátát a hamutartalom függvényében. Az ábrán feltüntettük a regressziós egyenes egyenletét és a determinációs koefficiens értékét.

\section{4. ábra: $\mathbf{L}^{*}$ világossági koordináta a hamutartalom függvényében}

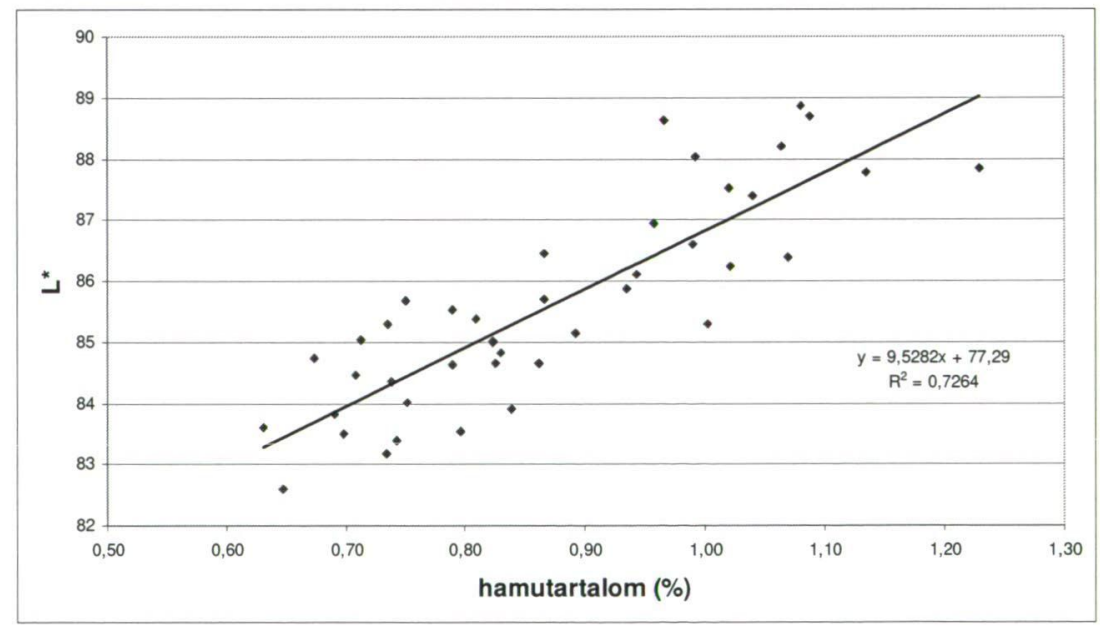

Megállapíthatjuk, hogy a hamutartalom és $\mathrm{L}^{*}$ világossági koordináta között szignifikáns lineáris kapcsolat van $(\mathrm{p}<0,01)$. A hamutartalom növekedésével L* világossági koordináta nő, tehát a magasabb hamutartalmú darák világosabbak.

Az 5. ábrán láthatjuk a különböző mintákon mért a* pirossági koordinátát a hamutartalom függvényében. Az ábrán feltüntettük a regressziós egyenes egyenletét 
és a determinációs koefficiens értékét. Megállapíthatjuk, hogy a hamutartalom és a* pirossági koordináta között szignifikáns lineáris kapcsolat van $(\mathrm{p}<0,01)$. A hamutartalom növekedésével a* világossági koordináta csökken, tehát a magasabb hamutartalmú darák kevésbé piros árnyalatúak.

\section{5. ábra: Az a* pirossági koordináta a hamutartalom függvényében}

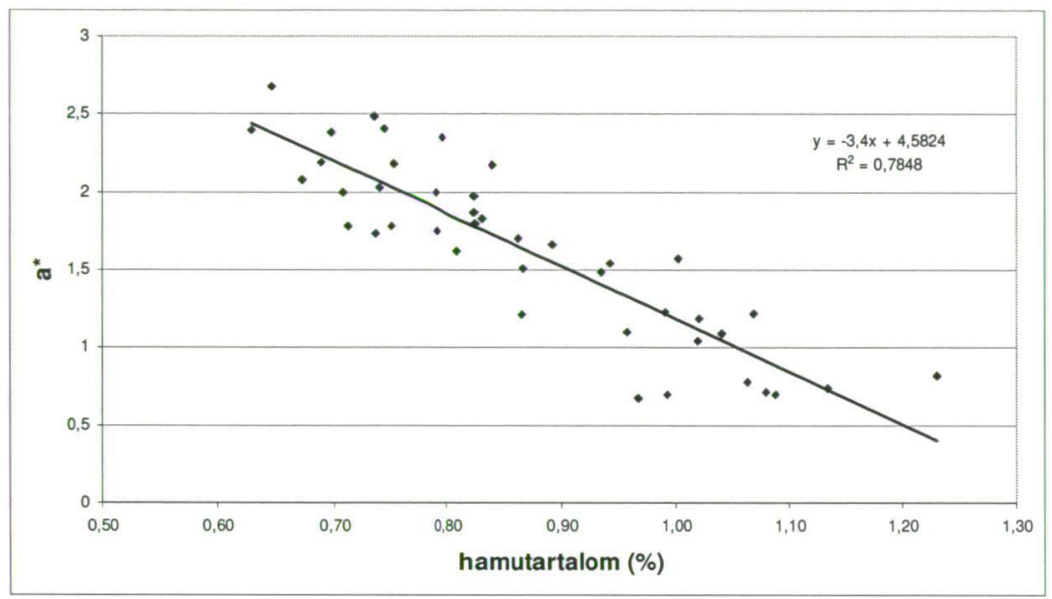

6. ábra: $\mathbf{A}$ b* sárgasági koordináta a hamutartalom függvényében

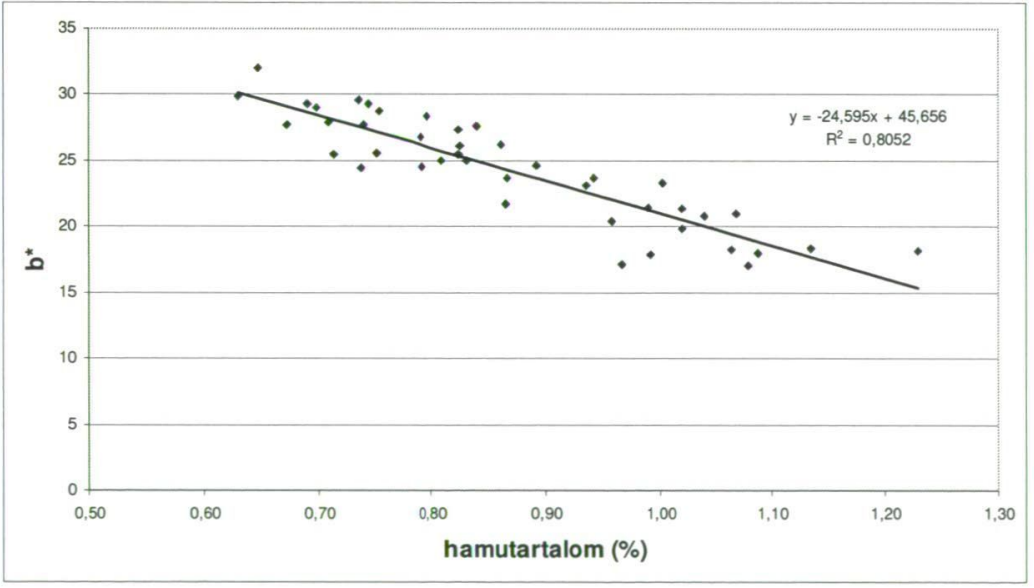

A 6. ábrán láthatjuk a különböző mintákon mért b* sárgasági koordinátát a hamutartalom függvényében. Az ábrán feltüntettük a regressziós egyenes egyenletét és a determinációs koefficiens értékét. Megállapíthatjuk, hogy a hamutartalom és b* sárgasági koordináta között szignifikáns lineáris kapcsolat van $(\mathrm{p}<0,01)$. A hamutartalom növekedésével $\mathrm{b}^{*}$ sárgasági koordináta csökken, tehát a magasabb hamutartalmú darák kevésbé sárgák. 
A 7. ábrán láthatjuk a különböző mintákon mért YI sárgasági index a hamutartalom függvényében. Az ábrán feltüntettük a regressziós egyenes egyenletét és a determinációs koefficiens értékét.

\section{7. ábra: YI sárgasági index a hamutartalom függvényében}

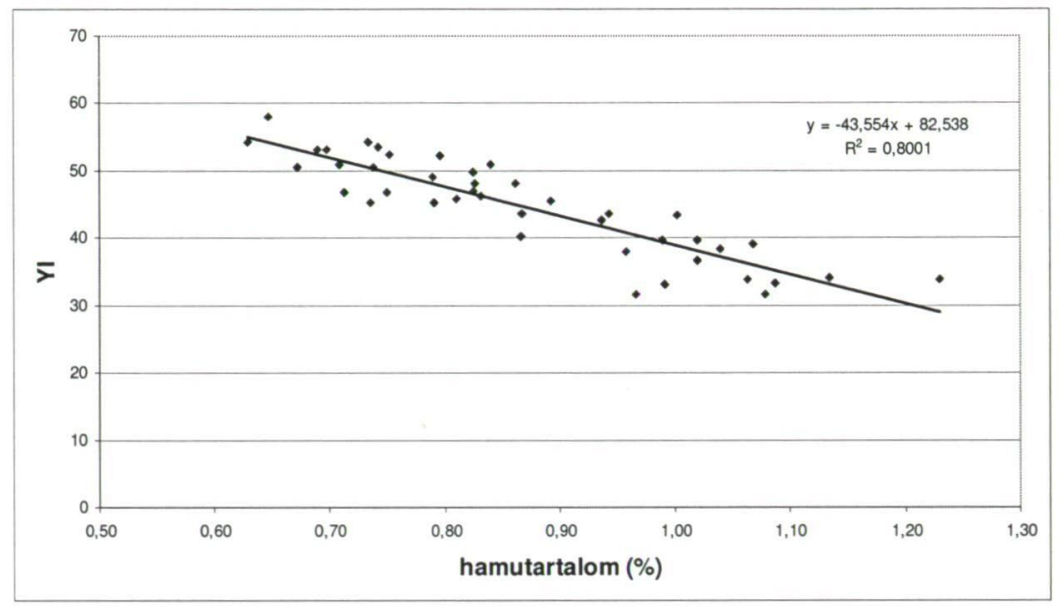

Megállapíthatjuk, hogy a hamutartalom és YI sárgasági index között hasonló szignifikáns lineáris kapcsolat van $(\mathrm{p}<0,01)$, mint a hamutartalom és a sárgasági koordináta között. A hamutartalom növekedésével YI sárgasági index csökken, tehát a magasabb hamutartalmú darák kevésbé sárgák.

\section{Következtetések}

Vizsgálataink során 12 durumdara különböző szemcseméret frakcióinak műszerrel mért színjellemzőit és hamutartalmát elemeztük. Az adatok statisztikai elemzés alapján a következő megállapításokat tettük.

- A szemcseméret szignifikánsan befolyásolja L* világossági, a* pirossági és b*sárgasági koordinátát, valamint YI sárgasági index alakulását.

- A szemcseméret növekedésével a hamutartalom csökken. Az átlagos hamutartalom $0,7 \%$ és $1,1 \%$ között változott. A teljes őrlemény hamutartalma a $315 \mu \mathrm{m}-500 \mu \mathrm{m}$ frakció hamutartalmával egyezik meg. Az egymást követő szemcseméret frakció hamutartalma között átlagosan $0,1 \%$ a különbség.

- A hamutartalom és minden egyes színjellemző között szignifikáns lineáris kapcsolat van $(\mathrm{p}<0,01)$.

\section{Irodalomjegyzék}

D’Egidio, M., Pagani, M. (1997): Effect of the different stage of durum wheat chain on pasta colour. Italian Food \& Beverage Technology, 10. (1997): 17-20.

Gökmen, V., Şenyuva, H. Z. (2006): Study of colour and acrylamide formation in coffee, wheat flour and potato chips during heating. Food Chemistry, 99: 238-243. 
Halászné-Fekete M., Záhonyiné-Racs P., Keleti Á. (1995): Colour measurement of durum grists for aim of qualification in paste industry. Book of the $\mathrm{XXV}^{\text {th }}$ Colouristic Symposium, 41-48.

Horváth Zs., Fekete M., Lakatos A. (2004): Instrumental Colour Measuring for weathen grits. Cercetarea Stiintifica O Punte Spre Integrarea Europeana Simpozionului $\mathrm{Cu}$ Participare Internationala, Arad, Analele.

Hotti, A. S, Sidhu, J., Al-Sager, J. (2000): Utililty of CIE tristimulus system in measuring the objective crumb colour of high-fibre toast bread formulation. Journal of Food Quality, 23 (1): 103-116.

Humphries M. J., Graham R. D., Mares D. J. (2005): Application of reflectance colour measurement to the estimation of carotene and lutein content in wheat and triticale. Journal of Cereal Science, 40: $151-159$.

Konopka I., Kozirok W., Rotkiewicz D. (2004): Lipids and carotenoids of wheat grain and flour and attempt of correlating them with digital image analysis of kernel surface and cross-sections. Food Research International, 37: 429-438.

Lamsal, B. P., Faubion, J. M. (2009): Effect of an enzyme preparation on wheat flour and dough color, mixing, and test baking. Food Science and Technology, 42: 1461-1467.

László Zs., Hovorka-Horváth Zs., Beszédes S., Kertész Sz., Gyimes E., Hodúr C. (2008): Comparison of the effects of ozone, UV and combined ozone/UV treatment on the colour and microbial counts of wheat flour. Ozone Science \& Engineering Joumal, 30: 419-417.

Lukács Gy (1983).: Színmérés. Müszaki Kiadó, Budapest.

Oliver, J., Blakeney, A., Allen, H. (1997): The colour of fluor strems related to ash and pigment contents. Journal of Cereal Science, 17: 169-182. 